\title{
An efficient and practical entry to 2-amido-dienes and 3-amido-trienes from allenamides through stereoselective 1,3-hydrogen shifts
}

\author{
Ryuji Hayashi, John B. Feltenberger, Andrew G. Lohse, Mary C. Walton
}

and Richard P. Hsung ${ }^{*}$

\section{Full Research Paper}

Address:

Department of Chemistry and Division of Pharmaceutical Sciences,

University of Wisconsin, Madison, WI 53705

\section{Email:}

Ryuji Hayashi - rhayashi@wisc.edu; John B. Feltenberger jfelten@chem.wisc.edu; Andrew G. Lohse - lohse@wisc.edu; Mary C. Walton - mcwalton@wisc.edu; Richard P. Hsung ${ }^{*}$ rhsung@wisc.edu

* Corresponding author

Keywords:

allenamides; 2-amido-dienes; 3-amido-trienes; electrocyclic ring-closure; 1,3-hydrogen shift; isomerization

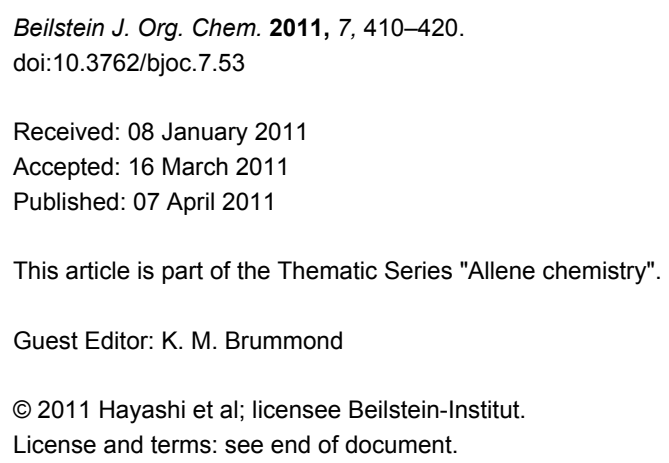

\begin{abstract}
Preparations of de novo acyclic 2-amido-dienes and 3-amido-trienes through 1,3-hydrogen shifts from allenamides are described. These 1,3-hydrogen shifts could be achieved thermally or they could be promoted by the use of Brønsted acids. Under either condition, these processes are highly regioselective in favour of the $\alpha$-position, and highly stereoselective in favour of the $E$-configuration. In addition, $6 \pi$-electron electrocyclic ring-closure could be carried out with 3-amido-trienes to afford cyclic 2-amido-dienes, and such electrocyclic ring-closure could be rendered in tandem with the 1,3-hydrogen shift.
\end{abstract}

\section{Introduction}

While allene isomerization to afford conjugated dienes is a well-known and thermodynamically favourable process, it is not trivial kinetically. A concerted allene isomerization leading to a diene involves a 1,3-hydrogen shift, which constitutes a fourelectron $(2 \pi+2 \sigma)$ process that needs an antarafacial approach to fulfil the anti-Hückel (or Möbius) transition state based upon the Woodward-Hoffman rules [1]. Although there is no experimental precedent in an actual allylic system, it is relatively more feasible for an allenic system due to the presence of orthogonally oriented p-orbitals of the sp-hybridized central allenic carbon (Scheme 1), allowing a formal phase change required for an anti-Hückel transition state (in blue, for references on a 

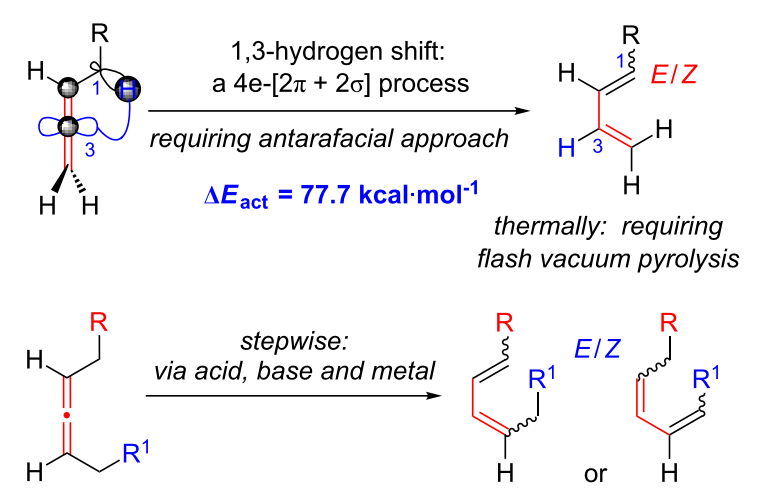

Scheme 1: 1,3-Hydrogen shifts of allenes.

possible radical pathway, see [2]), and a six-electron $(2 \pi+2 \sigma+$ $2 \pi$ ) process when considering the possible involvement of the second set of allenic $\pi$-electrons. Nevertheless, the calculated $\Delta E_{\text {act }}$ value remains high at $77.7 \mathrm{kcal} \cdot \mathrm{mol}^{-1}$ [2]. Whether concerted or not, most thermal isomerizations of allenes require severe reaction conditions (for general reviews on allenes see [3], for some examples of thermal isomerization of exocyclic allenes to dienes via radical intermediates see [4-12]), whereby controlling $E / Z$ ratios of the resulting diene remains a difficult problem. On the other hand, a stepwise isomerization of allenes via acid-, base-, or metal-mediated conditions seem to be more practical, but known examples have issues in controlling stereoand regioselectivity [3] (for some examples see [13-20]). Therefore, solving these problems can be highly significant.
Because of the popularity of dienes as one of the most utilized organic building blocks, a number of stereoselective preparations are known. The major question here is how viable is it to access conjugated dienes from structurally more challenging allenes through a kinetically difficult and stereochemically undistinguished isomerization. It might not seem like a logical approach; however, our justification is that since there are few well established routes for preparing amido-dienes, our allenamide isomerization strategy (for reviews on allenamide chemistry see [21-23], for reports in 2009, 2010 and 2011 see [24-43], for earlier studies on allenamides see [44-46]) can open the door to construct synthetically useful amido-dienes (for a review on the synthesis of enamides see [47], for reviews on the chemistry of dienamides see [48-50], for reviews on the chemistry of 2-amino or 2-amido-dienes see [51,52]). Problems with the two primary approaches to access amido-dienes [47] are that acid-mediated condensations suffer from functional group tolerances, and metal-mediated coupling methods (for reviews on $\mathrm{Cu}$-mediated $\mathrm{C}-\mathrm{N}$ and $\mathrm{C}-\mathrm{O}$ bond formations see [53-55], for some examples see [56-58]) suffer from limited access as well as the instability of halo-dienes (Scheme 2).

In contrast, multi-substituted allenamides can be concisely prepared through $\alpha$-alkylations of a parent allenamide [47,59] (for the synthesis of parent allenamides see [60]) or amidative cross-couplings of allenyl halides [61,62]. Therefore, our allenamide isomerization strategy has a much greater synthetic potential in constructing amido-dienes. While the chemistry of 1-amido-dienes has been explored in some detail (see Scheme 3 for success in preparing 1-amido-dienes via allenamide isomer- $\alpha$-alkylation of parent allenamides<smiles>[R]C([R])C(=CC)N1CCOC1=O</smiles>
$\alpha$-isomerization<smiles>O=C1NCCO1</smiles><smiles>[R]CC(=O)C=CC(=O)C(C)(C)C(=O)O</smiles>

challenges: functional group compatibility; or tolerance of acid sensitive substituents
Trost-Hsung $N$-allenylation protocol

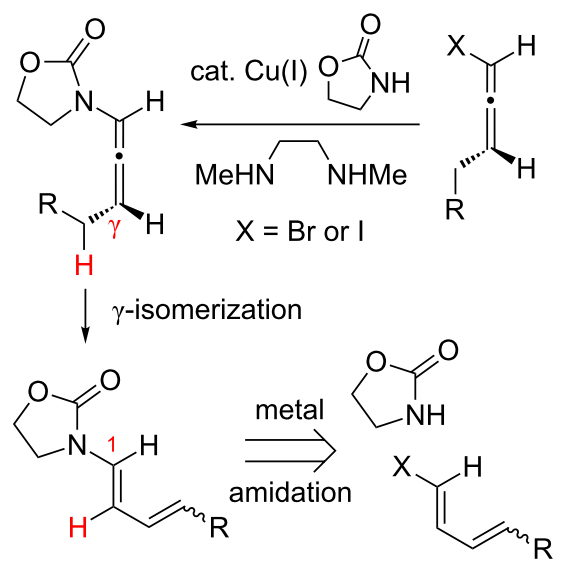

challenges: accessibility of the halo-dienes in a stereoselective manner 
izations) $[63,64]$ (for examples see [65-72]), herein, we report details of an efficient entry to synthetically rare 2-amido-dienes [73-77] via a regio- and stereoselective 1,3-hydrogen shift of allenamides.

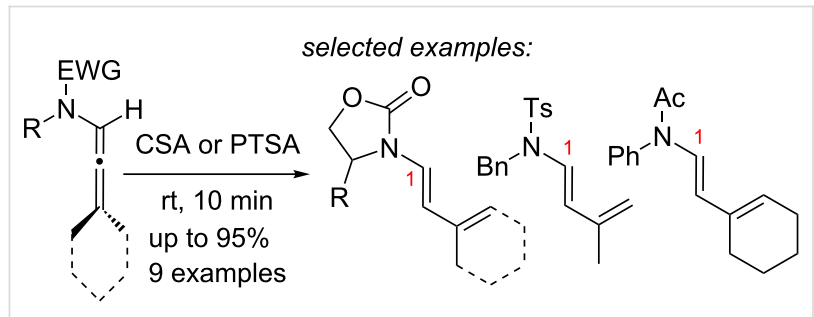

Scheme 3: Synthesis of 1-amido-dienes from allenamides.

\section{Results and Discussion}

As part of our initial screening efforts, both the thermal and acidic conditions were investigated as shown in Table 1. Allenamide 1 smoothly underwent isomerization via a 1,3hydrogen shift when heated at $115^{\circ} \mathrm{C}$ in $\mathrm{CH}_{3} \mathrm{CN}$ (sealed tube) to give the desired 2-amido-diene product $\mathbf{2}$ in $78 \%$ isolated yield with a $16: 1 E / Z$ selectivity (Table 1 , entry 1 ). There appears to be some solvent effect on the $E / Z$ selectivity with more polar solvents providing the best ratio (Table 1, entries 2-4). In addition to thermal conditions, we screened several Brønsted acids at room temperature in order to investigate a milder condition. While PTSA resulted in poor $E / Z$ ratio (Table 1, entry 5), a range of Brønsted acids were quite effective in affording the desired 2-amido-diene 2 (Supporting Information File 1 and Supporting Information File 2) with excellent $E / Z$ selectivity [Table 1 , entries 6-9].
After having established the 1,3-hydrogen shift under thermal and protic conditions, a diverse array of 2-amido-dienes was prepared as summarized in Table 2. Some notable features are: (1) a variety of novel chiral 2-amido-dienes $\mathbf{8}-\mathbf{1 0}$ were obtained from chiral allenamides 5-7 in synthetically useful yields and with high $E / Z$ ratios $(\geq 95: 5)$ under both thermal or acidic conditions (Table 2, entries 2-12); (2) unsubstituted 2-amido-dienes $\mathbf{8 d}$ and $9 \mathbf{c}$ could also be prepared in good yields ( Table 2, entries 7 and 10); (3) even allenamide containing an acyclic carbamate such as $\mathbf{1 1}$ underwent an efficient 1,3hydrogen shift; and (4) the X-ray structure (Supporting Information File 3) of a single crystal of 2-amido-diene 10b was successfully obtained to assign unambiguously the $E$-configuration (Figure 1).

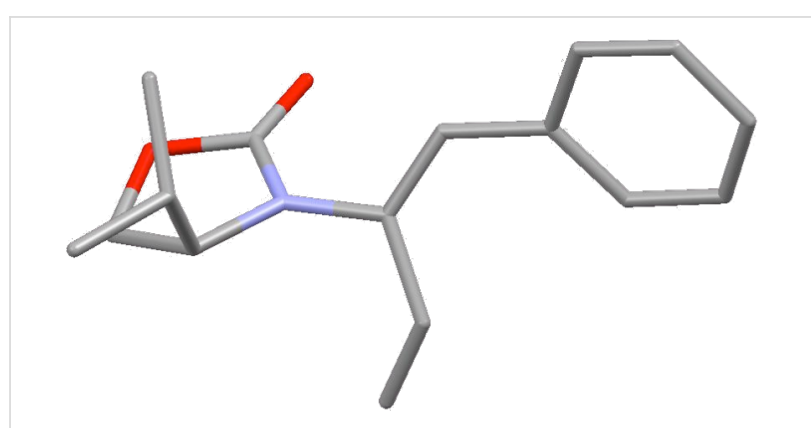

Figure 1: X-ray Structure of $10 \mathrm{~b}$.

Encouraged by this highly stereoselective isomerization, we turned our attention to the possibility of constructing synthetically much more challenging 3-amido-trienes from allenamides through 1,3-hydrogen shifts. As shown in Table 3, to our satis-

Table 1: 1,3-Hydrogen shift of allenamides.
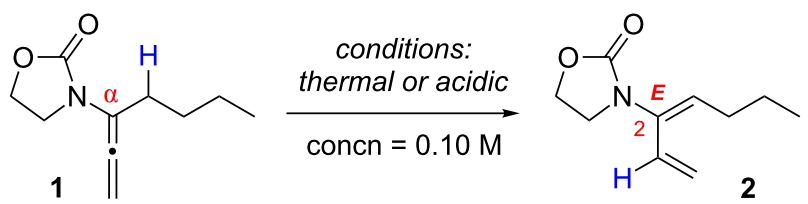

\begin{tabular}{|c|c|c|c|c|c|c|}
\hline entry & solvent & acid $[10 \mathrm{~mol} \%]$ & temp $\left[{ }^{\circ} \mathrm{C}\right]$ & time $[h]$ & yield $[\%]^{a, b}$ & $E: Z^{C}$ \\
\hline 1 & $\mathrm{CH}_{3} \mathrm{CN}$ & - & 115 & 16 & $91(78)$ & $16: 1$ \\
\hline 2 & THF & - & 115 & 16 & 51 & $9: 1$ \\
\hline 3 & $\mathrm{ClCH}_{2} \mathrm{CH}_{2} \mathrm{Cl}$ & - & 115 & 16 & 79 & $7: 1$ \\
\hline 4 & toluene & - & 150 & 16 & 55 & $4: 1$ \\
\hline 5 & $\mathrm{CH}_{2} \mathrm{Cl}_{2}$ & p-toluenesulfonic acid (PTSA) & 25 & 1 & 66 & $2: 1$ \\
\hline 6 & $\mathrm{CH}_{2} \mathrm{Cl}_{2}$ & $p-\mathrm{NO}_{2}-\mathrm{ArCO}_{2} \mathrm{H}$ & 25 & 16 & 81 & $15: 1$ \\
\hline 7 & $\mathrm{CH}_{2} \mathrm{Cl}_{2}$ & $\mathrm{PhCO}_{2} \mathrm{H}$ & 25 & 16 & $85(55)$ & $18: 1$ \\
\hline 8 & $\mathrm{CH}_{2} \mathrm{Cl}_{2}$ & pyridinium $p$-toluenesulfonate (PPTS) & 25 & 16 & 77 & $15: 1$ \\
\hline 9 & $\mathrm{CH}_{2} \mathrm{Cl}_{2}$ & camphorsulfonic acid (CSA) & 25 & $10 \min$ & $95(74)$ & 18:1 \\
\hline
\end{tabular}

aNMR yields. ${ }^{\mathrm{b}}$ Isolated yields are shown in brackets. ${ }^{\mathrm{C}}$ Ratios were determined by ${ }^{1} \mathrm{H}$ NMR. 
Table 2: Synthesis of 2-amido-dienes.

\begin{tabular}{|c|c|c|c|c|c|c|}
\hline entry & allenamides & & conditions (time) $)^{a}$ & amido-dienes & & yield $[\%]^{\mathrm{b}, \mathrm{c}}$ \\
\hline 1 & & 3 & $115^{\circ} \mathrm{C}(16 \mathrm{~h})$ & & 4 & 71 \\
\hline 2 & & $5 \mathrm{a}: \mathrm{R}=n-\mathrm{Pr}$ & $115^{\circ} \mathrm{C}(6 \mathrm{~h})$ & & $8 a$ & 77 \\
\hline 3 & & 5a: $\mathrm{R}=n-\mathrm{Pr}$ & $\operatorname{CSA}(4 h)^{d}$ & & $8 a$ & 87 \\
\hline 4 & & $5 b: R=P h$ & $115^{\circ} \mathrm{C}(16 \mathrm{~h})$ & & $8 b$ & 74 \\
\hline 5 & & 5b: $R=P h$ & $\operatorname{CSA}(2 \mathrm{~h})$ & & $8 b$ & 83 \\
\hline 6 & & $5 a: R={ }^{2} \mathrm{Nap}^{\mathrm{e}}$ & $115^{\circ} \mathrm{C}(16 h)^{f}$ & $\mathrm{Bñ}$ & $8 c$ & 73 \\
\hline 7 & & 5a: $\mathrm{R}=\mathrm{H}$ & $115^{\circ} \mathrm{C}(16 \mathrm{~h})$ & & $8 d$ & 69 \\
\hline 8 & & 6a: $\mathrm{R}=n-\mathrm{Pr}$ & CSA (10 min) & & $9 a$ & 82 \\
\hline 9 & & 6b: $\mathrm{R}=\mathrm{Ph}$ & CSA (10 min) & & $9 b$ & 76 \\
\hline 10 & & 6c: $R=H$ & $115^{\circ} \mathrm{C}(16 \mathrm{~h})$ & & $9 c$ & 69 \\
\hline 11 & & $7 \mathrm{a}: \mathrm{R}=n-\mathrm{Pr}$ & $115^{\circ} \mathrm{C}(16 \mathrm{~h})$ & & $10 a$ & 62 \\
\hline 12 & & 7b: $R=P h$ & $115^{\circ} \mathrm{C}(16 \mathrm{~h})$ & & $10 \mathrm{~b}$ & 82 \\
\hline 13 & $\mathrm{Bac} \mathrm{H}$ & 11 & $135^{\circ} \mathrm{C}(16 \mathrm{~h})$ & Boc & 12 & 45 \\
\hline 14 & & 11 & $\operatorname{CSA}^{\mathrm{g}}(2 \mathrm{~h})$ & & 12 & 61 \\
\hline
\end{tabular}

aUnless otherwise indicated, $\mathrm{CH}_{3} \mathrm{CN}$ was the solvent for thermal conditions and $\mathrm{CH}_{2} \mathrm{Cl}_{2}$ was the solvent when using 10 mol $\%$ of $\mathrm{CSA}$ at rt. For all reactions, concn $=0.10 \mathrm{M}$. ${ }^{\mathrm{b}} \mathrm{All}$ are isolated yields. ${ }^{\mathrm{c} A l l} 1,3-\mathrm{H}$ shifts were highly $E$-selective $[\geq 95: 5]$ except for entry 1 in which the $E: Z$ ratio is $6: 1$ for 4 . Ratios were determined by ${ }^{1} \mathrm{H}$ NMR. ${ }^{\mathrm{d}} \mathrm{Temp}$ started at $-78{ }^{\circ} \mathrm{C}$. ${ }^{\mathrm{e}}$ The group ${ }^{2} \mathrm{Nap}$ stands for 2-naphthyl. ${ }^{\mathrm{f}} \mathrm{ClCH}_{2} \mathrm{CH}_{2} \mathrm{Cl}_{\text {was }}$ used. ${ }^{9} \AA \AA \mathrm{MS}$ was used.

faction, a wide variety of 3-amido-trienes could be readily accessed from corresponding $\alpha$-allylated allenamides. When using a catalytic amount of CSA, both achiral and chiral 3 -amido-trienes were obtained in high yields with exclusive $E$-selectivity, including structurally intriguing examples such as 24-28 (Table 3, entries 9-15). Moreover, a protected alcohol or amine in the allenamide did not impede the isomerization process (Table 3, entries 10-14), leading to more functionalized trienes.

To continue elevating the level of complexity, we examined allenamides with both $\alpha$ - and $\gamma$-substitutions and hoped to observe regioselectivity during the 1,3-hydrogen shift. Consequently, as shown in Table 4, isomerizations of tetra-substituted allenamides were examined. When heating $\alpha$ - and $\gamma$-substituted allenamides 29a and 30 in $\mathrm{CH}_{3} \mathrm{CN}$ at $115^{\circ} \mathrm{C}$ in a sealed tube, 1,3-hydrogen shift took place exclusively from the $\alpha$-position affording highly substituted $(E)$-2-amido-dienes 33a and 34 in $71 \%$ and $79 \%$ yields, respectively (Table 4, entries 1 and 3). The E-geometry in 33a and $\mathbf{3 4}$ was assigned by NOE (Supporting Information File 2).

Intriguingly, allenamide 29b underwent a 1,3-hydrogen shift at room temperature when simply in contact with silica gel during the purification stage; but again, only the 1,3-hydrogen shift was favoured proceeding from the $\alpha$-position to give $(E)-2-$ amido-diene 33b (Table 4, entry 2 ). In addition, highly substituted 3-amido-trienes $\mathbf{3 5 a}, \mathbf{3 5 b}$, and $\mathbf{3 6}$ were regioselectively synthesized in overall high yields using the CSA-catalyzed conditions (Table 4, entries 4-6). Not only are the products from this regioselective isomerization structurally unique, but also mechanistically intriguing. 


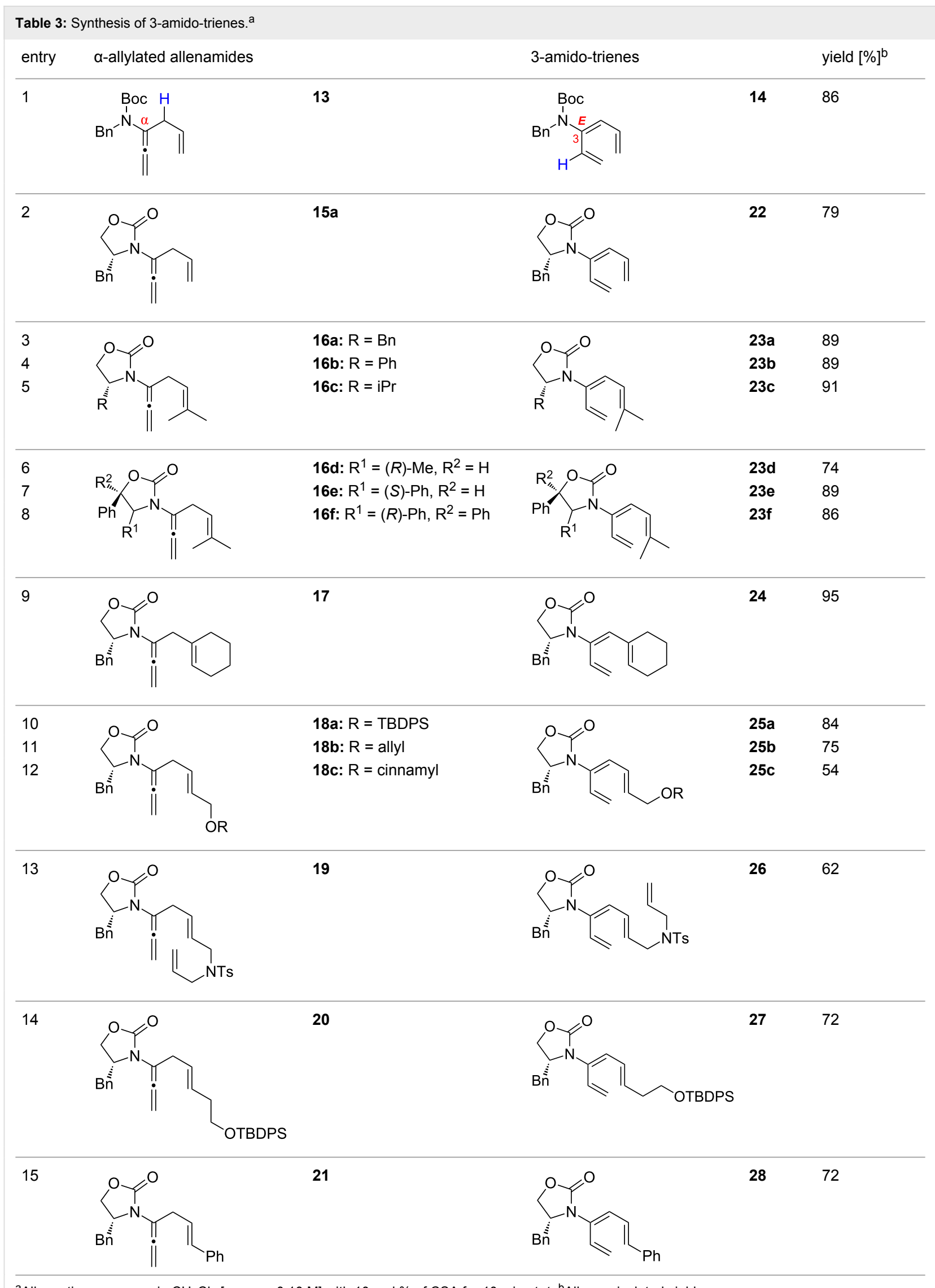

aAll reactions were run in $\mathrm{CH}_{2} \mathrm{Cl}_{2}$ [concn $=0.10 \mathrm{M}$ ] with $10 \mathrm{~mol} \%$ of CSA for $10 \mathrm{~min}$ at rt. ${ }^{\mathrm{b}} \mathrm{All}$ were isolated yields. 


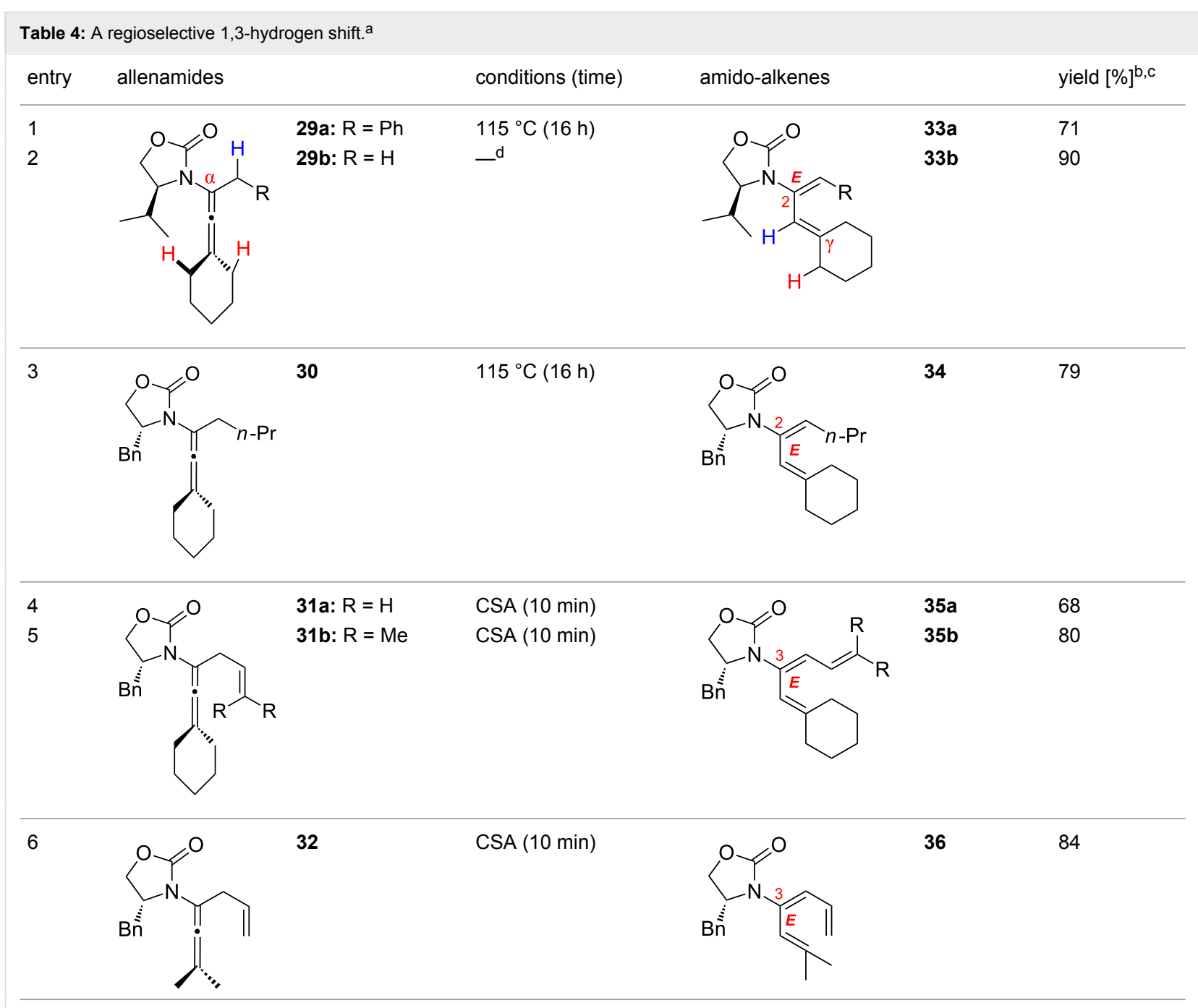

aUnless otherwise noted, $\mathrm{CH}_{3} \mathrm{CN}$ was the solvent for thermal conditions and $\mathrm{CH}_{2} \mathrm{Cl}_{2}$ was the solvent when using $10 \mathrm{~mol} \%$ of $\mathrm{CSA}$ at rt. For all reactions, concn $=0.10 \mathrm{M}$. ${ }^{\mathrm{b}} \mathrm{All}$ were isolated yields. ${ }^{\mathrm{c}} \mathrm{All}$ amido-di- and trienes were exclusively $E$-selective $[\geq 95: 5]$. ${ }^{\mathrm{d}}$ See text for this isomerization.

One of the probable explanations for the significantly lowered thermal activation barrier of 1,3-hydrogen-shifts of allenamides is that the nitrogen atom can serve to stabilize the biradical intermediate [2,4-12] (for another leading reference on related radical intermediates see [78]) which are presumed to be electron deficient. Based on the model in Figure 2 (left side), stabilization of the biradical intermediate is direct when isomerizations proceed from the $\alpha$-position, whereas the isomerization from the $\gamma$-position is "vinylogous", or remotely stabilized through the olefin. Therefore, thermal isomerizations at the $\alpha$-position should be faster than at the $\gamma$-position.

While under thermal conditions, a biradical intermediate is at play $[2,4,24]$, under acidic conditions, the isomerization clearly proceeds through an $\mathrm{N}$-acyl iminium intermediate via protonation of the allenamide (Figure 2, center). Consequently, a similar argument could be used to rationalize the regioselective 1,3-hydrogen shift when acid was used. It is noteworthy that this charged transition state could also be adopted for the thermal isomerization. While still being a neutral transition state, the nitrogen atom could facilitate a polarized transition state through increasing negative charge density at the $\beta$-carbon. This action would lead to an $\mathrm{N}$-acyl iminium ion-like character with the migrating hydrogen being proton-like with the $\alpha$-position being favoured. This polarized transition state should also have a lower thermal activation barrier for the 1,3-hydrogen shift than the neutral one.

Lastly, a non-radical proton-transfer like mechanism could also be at play under conditions using protic solvents or owing to the presence of trace of amount of water (Figure 2, right). These last two models also reveal some insight into the $E$-selectivity given the pro- $E$ configured transition state (TS) (see the $\mathrm{R}^{1}$ group). Along the same line, if the reaction proceeds through a 


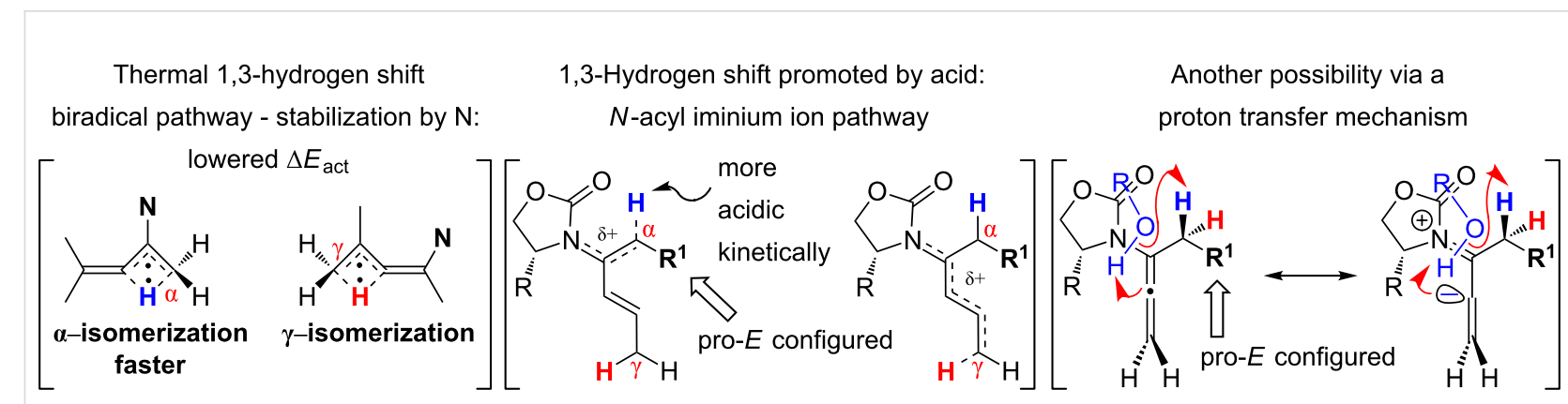

Figure 2: Proposed mechanistic models.

radical pathway, the observed $E$-selectivity in the thermal 1,3hydrogen shift should be favoured because the pro- $Z$ transition state experiences a greater allylic strain compared to the pro- $E$ transition state (Scheme 4). A thermodynamically driven equilibration from $(Z)$ - to $(E)$-enamide post-isomerization is a real possibility that cannot be ruled out, and the observed solvent effect on the $(E / Z)$-selectivity would particularly support this possible notion.
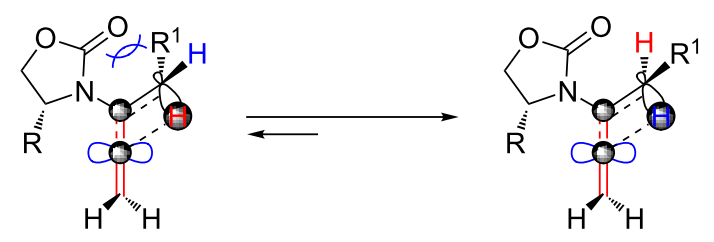

pro-Z

An interesting discovery was made during this work. As shown in Scheme 5, when subjected to CSA catalyzed isomerization for protected allyl alcohol-substituted allenamides, the reactions with 37a and $\mathbf{3 7 b}$ did not stop at the intermediate $\mathbf{3 8}$, but an unexpected 1,7-H-shift (for some examples of an antarafacial 1,7-H shift see [79-82]) took place at room temperature to afford 5-amido-trienes 39a and 39b stereoselectively in good yields. Furthermore, when heating the protected homo-allyl alcohol-substituted allenamide 40, after the 1,3-hydrogen shift an unprecedented double 1,7-H-shift through intermediate 41 and $\mathbf{4 2}$ took place to afford the 6-amido-triene $\mathbf{4 3}$ in $45 \%$ yield. It is noteworthy that amido-triene $\mathbf{4 1}$ could be isolated in $65 \%$ yield when using $10 \mathrm{~mol} \% \mathrm{CSA}$.

The synthesis of 3 -amido-trienes from $\alpha$-isomerization of allenamides allowed us to explore an important pericyclic process for yet another amido-diene synthesis. As shown in Scheme 6, isomerizations of $\alpha$-allylated allenamides $\mathbf{1 5} \mathbf{a}$ and 13 under acidic conditions can afford 3-amido-trienes 22 and $\mathbf{1 4}$ in excellent yields. Given the $E$-selectivity of this isomerization,

Scheme 4: A favored pro-E TS.

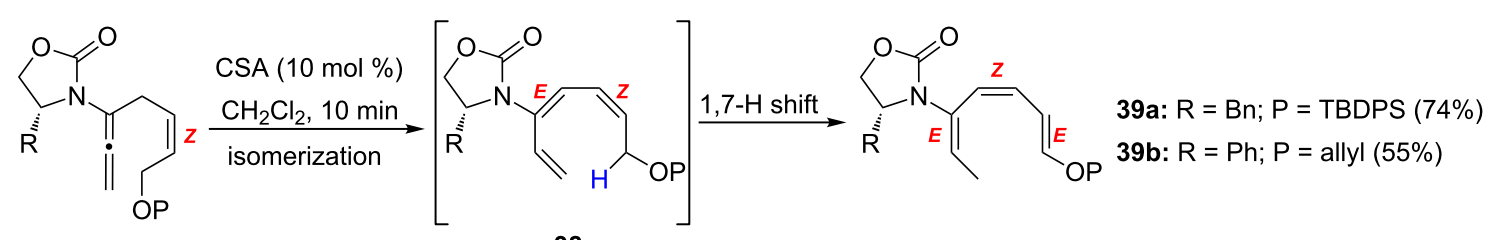

37a: $R=B n ; P=T B D P S$

38

37b: $R=P h ; P=$ allyl

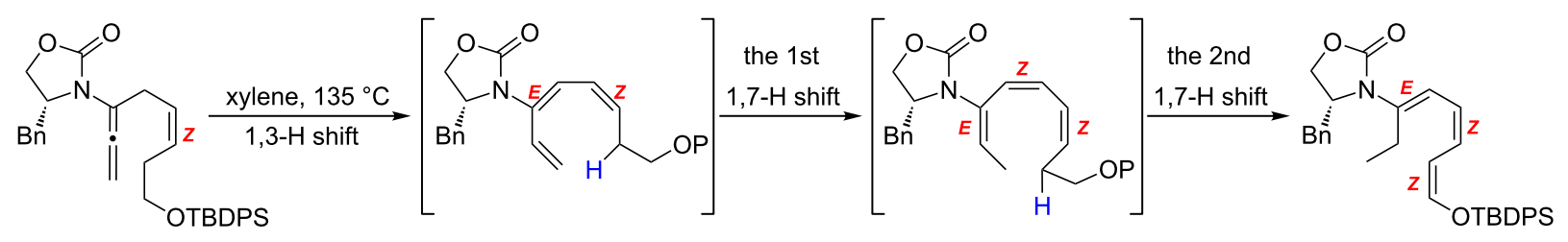

40

41

42: $P=$ TBDPS

43: $45 \%$ 
<smiles>C=CCC(=C)N1C(=O)OC[C@H]1Br</smiles>

$15 a$<smiles>C=C/C=C\C(C=C)N1C(=O)OCC1[Hg]c1ccccc1</smiles>

22: $89 \%$ yield; $E$ only

\section{$6 \pi$-ring-closure

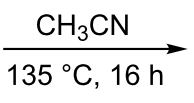

44a: $84 \%$ yield

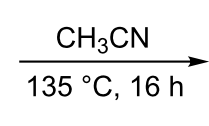

14: $86 \%$ yield; $E$ only

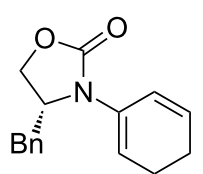<smiles>CC(C)(C)OC(=O)N(Cc1ccccc1)C1=CCCC=C1</smiles>

45: $35 \%$ yield

Scheme 6: Applications in pericyclic ring-closure.

these 3-amido-trienes are perfectly suited for thermal $6 \pi$-electron electrocyclic ring-closure (for reviews on pericyclic ringclosures see $[83,84]$, for reviews on ring-closure in natural product synthesis see $[85,86]$, for recent examples of $6 \pi$-electron electrocyclic ring-closure see [87-93], for examples on accelerated ring-closures of 1,3,5-hexatrienes see [94-99]) to access cyclic 2-amido-dienes that are quite rare (for examples see [100-102]). Chiral amido-triene 22 underwent electrocyclization efficiently to give chiral cyclic 2 -amido-diene $44 \mathrm{a}$ in $84 \%$ yield. Although obtained in only $35 \%$ yield, the achiral cyclic 2-amido-diene 45 could also be prepared.

Finally, this overall process was rendered in tandem under thermal conditions to directly prepare cyclic 2-amido-dienes 44a-c from allenamides $15 \mathbf{a}-\mathbf{c}$, respectively, in good yields (Scheme 7). Notably these $6 \pi$-electron pericyclic ring-closures took place at relatively low temperature $\left(135^{\circ} \mathrm{C}\right)$, thereby implying an accelerated process of electrocyclization. This feature is consistently observed in related ring-closures of 1,3,5hexatrienes with an electron-donating substituent at the $\mathrm{C} 3$ position of the triene [94-99] (for theoretical studies on substituent effects on electrocyclic ring-closures of 1,3,5-hexatrienes see [97,103-105]. It is also noteworthy that while acyclic 2-amido-

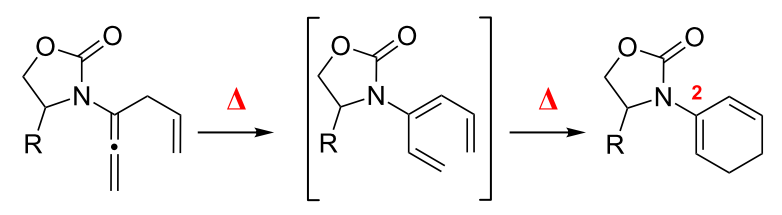

$\begin{array}{ll}\text { 15a: } R=(R)-\mathrm{Bn} & \mathrm{R}=\mathrm{Bn}: \mathrm{CH}_{3} \mathrm{CN}, 135^{\circ} \mathrm{C}, 16 \mathrm{~h}: 44 \mathrm{a}: 43 \% \text { yield } \\ \text { 15b: } \mathrm{R}=\mathrm{H} & \mathrm{R}=\mathrm{H}: \mathrm{CH}_{3} \mathrm{CN}, 115^{\circ} \mathrm{C}, 16 \mathrm{~h}: 44 \mathrm{~b}: 57 \% \text { yield } \\ \text { 15c: } \mathrm{R}=(S)-\mathrm{Pr} & \mathrm{R}=\mathrm{iPr}: \mathrm{CH}_{3} \mathrm{CN}, 135^{\circ} \mathrm{C}, 16 \mathrm{~h}: 44 \mathrm{c}: 54 \% \text { yield }\end{array}$

Scheme 7: Cyclic 2-amido-diene synthesis. dienes and 3-amido-trienes are synthetically challenging to make, cyclic amido-dienes are almost inaccessible synthetically [100-102].

\section{Conclusion}

Herein, we have accomplished the preparation of de novo acyclic 2-amido-dienes and 3-amido-trienes through 1,3hydrogen shifts from allenamides. These 1,3-hydrogen shifts could be achieved under thermal conditions or they could be promoted with Brønsted acids. Under either condition, these processes are highly regioselective in favour of the $\alpha$-position, and highly stereoselective in favour of the $E$-configuration. Additionally, $6 \pi$-electron electrocyclic ring-closure could be carried out from 3-amido-trienes to afford cyclic 2-amidodienes, and such electrocyclic ring-closure could be rendered in tandem with the 1,3-hydrogen shift, thereby constituting a facile construction of synthetically rare cyclic 2 -amido-dienes.

\section{Supporting Information}

Supporting Information features detailed information on synthesis, purification and characterization data of all substances given in this article, proton and selected carbon NMR spectra, and X-ray data of compound $\mathbf{1 0 b}$.

\section{Supporting Information File 1}

Experimental section.

[http://www.beilstein-journals.org/bjoc/content/ supplementary/1860-5397-7-53-S1.pdf]

\section{Supporting Information File 2}

Proton and Carbon NMR spectra, and NOE data. [http://www.beilstein-journals.org/bjoc/content/ supplementary/1860-5397-7-53-S2.pdf] 


\section{Supporting Information File 3}

$\mathrm{X}$-Ray structural analysis and information for compound $10 b$.

[http://www.beilstein-journals.org/bjoc/content/ supplementary/1860-5397-7-53-S3.res]

\section{Acknowledgements}

Authors thank NIH (GM066055) for financial support and Dr. Victor Young (University of Minnesota) for X-ray structural analysis.

\section{References}

1. Woodward, R. B.; Hoffmann, R. Angew. Chem., Int. Ed. Engl. 1969, 8, 781. doi:10.1002/anie.196907811

2. Jensen, F. J. Am. Chem. Soc. 1995, 117, 7487. doi:10.1021/ja00133a021

3. Krause, N.; Hashmi, A. S. K., Eds. Modern allene chemistry; Wiley-VCH: Weinheim, Germany, 2004.

4. Crandall, J. K.; Paulson, D. R. J. Am. Chem. Soc. 1966, 88, 4302. doi:10.1021/ja00970a063

5. Paulson, D. R.; Crandall, J. K.; Bunnell, C. A. J. Org. Chem. 1970, 35, 3708. doi:10.1021/j000836a027

6. Bloch, R.; Perchec, P. L.; Conia, J.-M. Angew. Chem., Int. Ed. Engl. 1970, 9, 798. doi:10.1002/anie.197007981

7. Jones, M.; Hendrick, M. E.; Hardie, J. A. J. Org. Chem. 1971, 36, 3061. doi:10.1021/jo00819a042

8. Patrick, T. B.; Haynie, E. C.; Probst, W. J. Tetrahedron Lett. 1971, 27, 423. doi:10.1016/S0040-4039(01)96457-3

9. Lenk, W.; Hopf, H. Tetrahedron Lett. 1982, 23, 4073. doi:10.1016/S0040-4039(00)88350-1

10. Hopf, H.; Gottschild, D.; Lenk, W. Isr. J. Chem. 1985, 26, 79.

11. Lehrich, F.; Hopf, H. Tetrahedron Lett. 1987, 28, 2697. doi:10.1016/S0040-4039(00)96184-7

12. Meier, H.; Schmitt, M. Tetrahedron Lett. 1989, 30, 5873. doi:10.1016/S0040-4039(01)93493-8

13. Tsuboi, S.; Masuda, T.; Takeda, A. J. Org. Chem. 1982, 47, 4478. doi:10.1021/jo00144a015

14. Peng, W.; Zhu, S. Tetrahedron 2003, 59, 4641. doi:10.1016/S0040-4020(03)00663-X

15. Al-Masum, M.; Yamamoto, Y. J. Am. Chem. Soc. 1998, 120, 3809. doi:10.1021/ja974223+

16. Bibas, H.; Koch, R.; Wentrup, C. J. Org. Chem. 1998, 63, 2619. doi:10.1021/jo972137m

17. Jacobs, T. L.; Johnson, R. N. J. Am. Chem. Soc. 1960, 82, 6397. doi:10.1021/ja01509a050

18. Buzas, A. K.; Istrate, F. M.; Gagosz, F. Org. Lett. 2007, 9, 985. doi:10.1021/ol063031t

19. Trost, B. M.; Kazmaier, U. J. Am. Chem. Soc. 1992, 114, 7933. doi:10.1021/ja00046a062

20. Guo, C.; Lu, X. J. Chem. Soc., Perkin Trans. 1 1993, 1921. doi:10.1039/P19930001921

21. Wei, L.-L.; Xiong, H.; Hsung, R. P. Acc. Chem. Res. 2003, 36, 773. doi:10.1021/ar030029i

22. Standen, P. E.; Kimber, M. C. Curr. Opin. Drug Discovery Dev. 2010, 13, 645 .
23. Deagostino, A.; Prandi, C.; Tabasso, S.; Venturello, P. Molecules 2010, 15, 2667. doi:10.3390/molecules15042667

24. Zhu, Y.; Yin, G.; Hong, D.; Lu, P.; Wang, Y. Org. Lett. 2011, 13, 1024. doi:10.1021/ol103074d

25. Yin, G.; Zhu, Y.; Zhang, L.; Lu, P.; Wang, Y. Org. Lett. 2011, 13, 940. doi:10.1021/ol102992n

26. Hayashi, R.; Walton, M. C.; Hsung, R. P.; Schwab, J. H.; Yu, X. Org. Lett. 2010, 12, 5768. doi:10.1021/ol102693e

27. Lohse, A. G.; Krenske, E. H.; Antoline, J. E.; Houk, K. N.; Hsung, R. P. Org. Lett. 2010, 12, 5506. doi:10.1021/ol1023745

28. Beccalli, E. M.; Bernasconi, A.; Borsini, E.; Broggini, G.; Rigamonti, M.; Zecchi, G. J. Org. Chem. 2010, 75, 6923. doi:10.1021/jo101501u

29. Hill, A. W.; Elsegood, M. R. J.; Kimber, M. C. J. Org. Chem. 2010, 75, 5406. doi:10.1021/jo101035n

30. Persson, A. K. Å.; Bäckvall, J.-E. Angew. Chem., Int. Ed. 2010, 49, 4624. doi:10.1002/anie.201000726

31. Krenske, E. H.; Houk, K. N.; Lohse, A. G.; Antoline, J. E.; Hsung, R. P. Chem. Sci. 2010, 1, 387. doi:10.1039/c0sc00280a

32. Danowitz, A. M.; Taylor, C. E.; Shrikian, T. M.; Mapp, A. K. Org. Lett. 2010, 12, 2574. doi:10.1021/ol1007845

33. Zbieg, J. R.; McInturff, E. L.; Krische, M. J. Org. Lett. 2010, 12, 2514. doi:10.1021/ol1007235

34. Cordier, P.; Aubert, C.; Malacria, M.; Gandon, V.; Lacôte, E. Chem.-Eur. J. 2010, 16, 9973. doi:10.1002/chem.201000914

35. Kimber, M. C. Org. Lett. 2010, 12, 1128. doi:10.1021/ol1001494

36. Hashimoto, K.; Horino, Y.; Kuroda, S. Heterocycles 2010, 80, 187 doi:10.3987/COM-09-S(S)54

37. Persson, A. K. A.; Johnston, E. V.; Bäckvall, J.-E. Org. Lett. 2009, 11, 3814. doi:10.1021/ol901294j

38. Skucas, E.; Zbieg, J. R.; Krische, M. J. J. Am. Chem. Soc. 2009, 131, 5054. doi:10.1021/ja900827p

39. Armstrong, A.; Emmerson, D. P. G. Org. Lett. 2009, 11, 1547. doi:10.1021/ol900146s

40. Beccalli, E. M.; Broggini, G.; Clerici, F.; Galli, S.; Kammerer, C.; Rigamonti, M.; Sottocornola, S. Org. Lett. 2009, 11, 1563. doi:10.1021/ol900171g

41. Broggini, G.; Galli, S.; Rigamonti, M.; Sottocornola, S.; Zecchi, G. Tetrahedron Lett. 2009, 50, 1447. doi:10.1016/j.tetlet.2009.01.074

42. Lohse, A. G.; Hsung, R. P. Org. Lett. 2009, 11, 3430. doi:10.1021/ol901283m

43. Lu, T.; Hayashi, R.; Hsung, R. P.; DeKorver, K. A.; Lohse, A. G.; Song, Z.; Tang, Y. Org. Biomol. Chem. 2009, 7, 3331. doi:10.1039/b908205k

44. Overman, L. E.; Clizbe, L. A.; Freerks, R. L.; Marlowe, C. K. J. Am. Chem. Soc. 1981, 103, 2807. doi:10.1021/ja00400a053

45. Farmer, M. L.; Billups, W. E.; Greenlee, R. B.; Kurtz, A. N. J. Org. Chem. 1966, 31, 2885. doi:10.1021/jo01347a035

46. Kinderman, S. S.; van Maarseveen, J. H.; Schoemaker, H. E.; Hiemstra, H.; Rutjes, F. P. J. T. Org. Lett. 2001, 3, 2045. doi:10.1021/ol016013e

47. Tracey, M. R.; Hsung, R. P.; Antoline, J.; Kurtz, K. C. M.; Shen, L.; Slafer, B. W.; Zhang, Y. Product Class 4: N-Arylalkanamides, Ynamides, Enamides, Dienamides, and Allenamides. In Science of Synthesis, Houben-Weyl Methods of Molecular Transformations; Weinreb, S. M., Ed.; Thieme: Stuttgart, 2005; pp 387-476.

48. Overman, L. E. Acc. Chem. Res. 1980, 13, 218. doi:10.1021/ar50151a005

49. Petrzilka, M.; Grayson, J. I. Synthesis 1981, 753. doi:10.1055/s-1981-29592 
50. Campbell, A. L.; Lenz, G. R. Synthesis 1987, 421. doi:10.1055/s-1987-27972

51. Krohn, K. Angew. Chem., Int. Ed. Engl. 1993, 32, 1582. doi:10.1002/anie.199315821

52. Enders, D.; Meyer, O. Liebigs Ann. 1996, 1023. doi:10.1002/jlac.199619960702

53. Lindley, J. Tetrahedron 1984, 40, 1433. doi:10.1016/S0040-4020(01)91791-0

54. Ley, S. V.; Thomas, A. W. Angew. Chem., Int. Ed. 2003, 42, 5400. doi:10.1002/anie.200300594

55. Dehli, J. R.; Legros, J.; Bolm, C. Chem. Commun. 2005, 973. doi:10.1039/b415954c

56. Klapper, A.; Huang, X.; Buchwald, S. L. J. Am. Chem. Soc. 2002, 124, 7421. doi:10.1021/ja0260465

57. Han, C.; Shen, R.; Su, S.; Porco, J. A., Jr. Org. Lett. 2004, 6, 27. doi:10.1021/ol0360041

58. Shen, R.; Lin, C. T.; Bowman, E. J.; Bowman, B. J.; Porco, J. A., Jr. J. Am. Chem. Soc. 2003, 125, 7889. doi:10.1021/ja0352350

59. Xiong, H.; Hsung, R. P.; Wei, L.-L.; Berry, C. R.; Mulder, J. A.; Stockwell, B. Org. Lett. 2000, 2, 2869. doi:10.1021/ol000181+

60. Wei, L.-L.; Mulder, J. A.; Xiong, H.; Zificsak, C. A.; Douglas, C. J.; Hsung, R. P. Tetrahedron 2001, 57, 459. doi:10.1016/S0040-4020(00)01014-0

61. Trost, B. M.; Stiles, D. T. Org. Lett. 2005, 7, 2117. doi:10.1021/ol050395x

62. Shen, L.; Hsung, R. P.; Zhang, Y.; Antoline, J. E.; Zhang, X. Org. Lett. 2005, 7, 3081. doi:10.1021/ol051094q

63. Hayashi, R.; Hsung, R. P.; Feltenberger, J. B.; Lohse, A. G. Org. Lett. 2009, 11, 2125. doi:10.1021/ol900647s

64. Hayashi, R.; Feltenberger, J. B.; Hsung, R. P. Org. Lett. 2010, 12, 1152. doi:10.1021/ol902821w

65. Terada, A.; Murata, K. Bull. Chem. Soc. Jpn. 1967, 40, 1644. doi:10.1246/bcsj.40.1644

66. Overman, L. E.; Clizbe, L. A. J. Am. Chem. Soc. 1976, 98, 2352. doi:10.1021/ja00424a068

67. Oppolzer, W.; Bieber, L.; Francotte, E. Tetrahedron Lett. 1979, 20, 4537. doi:10.1016/S0040-4039(01)86643-0

68. Smith, A. B., III; Wexler, B. A.; Tu, C.-Y.; Konopelski, J. P. J. Am. Chem. Soc. 1985, 107, 1308. doi:10.1021/ja00291a034

69. Schlessinger, R. H.; Pettus, T. R. R.; Springer, J. P.; Hoogsteen, K. J. Org. Chem. 1994, 59, 3246. doi:10.1021/jo00091a002

70. Kozmin, S. A.; Rawal, V. H. J. Am. Chem. Soc. 1997, 119, 7165. doi:10.1021/ja971272d

71. Huang, Y.; Iwama, T.; Rawal, V. H. J. Am. Chem. Soc. 2002, 124, 5950. doi:10.1021/ja026088t

72. Robiette, R.; Cheboub-Benchaba, K.; Peeters, D.; Marchand-Brynaert, J. J. Org. Chem. 2003, 68, 9809. doi:10.1021/jo0302049

73. Ha, J. D.; Kang, C. H.; Belmore, K. A.; Cha, J. K. J. Org. Chem. 1998, 63, 3810. doi:10.1021/jo980593k

74. González-Romero, C.; Bernal, P.; Jiménez, F.; Cruz, M. C.; Fuentes-Benites, A.; Benavides, A.; Bautista, R.; Tamariz, J. Pure Appl. Chem. 2007, 79, 181.

75. Movassaghi, M.; Hunt, D. K.; Tjandra, M. J. Am. Chem. Soc. 2006, 128, 8126. doi:10.1021/ja0626180

76. Enders, D.; Meyer, O.; Raabe, G. Synthesis 1992, 1242. doi:10.1055/s-1992-26349

77. Barluenga, J.; Canteli, R.-M.; Flórez, J.; García-Granda, S.; Gutiérrez-Rodríguez, A.; Martín, E. J. Am. Chem. Soc. 1998, 120, 2514. doi:10.1021/ja972588o
78. Siebert, M.; Osbourn, J. M.; Brummond, K. M.; Tantillo, D. J. J. Am. Chem. Soc. 2010, 132, 11952. doi:10.1021/ja102848z

79. Kerr, D. J.; Willis, A. C.; Flynn, B. L. Org. Lett. 2004, 6, 457. doi:10.1021/ol035822q

80. Mousavipour, S. H.; Fernández-Ramos, A.; Meana-Pañeda, R.; Martínez-Núñez, E.; Vázquez, S. A.; Ríos, M. A. J. Phys. Chem. A 2007, 111, 719. doi:10.1021/jp0665269

81. Gu, Z.; Ma, S. Chem.-Eur. J. 2008, 14, 2453. doi:10.1002/chem.200701171

82. Shu, X.-Z.; Ji, K.-G.; Zhao, S.-C.; Zheng, Z.-J.; Chen, J.; Lu, L.; Liu, X.-Y.; Liang, Y.-M. Chem.-Eur. J. 2008, 14, 10556. doi:10.1002/chem.200801591

83. Marvell, E. N. Thermal Electrocyclic Reactions; Academic Press: New York, 1980.

84. Okamura, W. H.; de Lera, A. R. In Comprehensive Organic Synthesis; Trost, B. M.; Fleming, I.; Paquette, L. A., Eds.; Pergamon Press: New York, 1991; Vol. 5, pp 699-750. doi:10.1016/B978-0-08-052349-1.00137-2

85. Pindur, U.; Schneider, G. H. Chem. Soc. Rev. 1994, 23, 409 doi:10.1039/cs9942300409

86. Beaudry, C. M.; Malerich, J. P.; Trauner, D. Chem. Rev. 2005, 105, 4757. doi:10.1021/cr0406110

87. Bishop, L. M.; Barbarow, J. E.; Bergmen, R. G.; Trauner, D. Angew. Chem., Int. Ed. 2008, 47, 8100. doi:10.1002/anie.200803336

88. Sofiyev, V.; Navarro, G.; Trauner, D. Org. Lett. 2008, 10, 149. doi:10.1021/ol702806v

89. Kan, S. B. J.; Anderson, E. A. Org. Lett. 2008, 10, 2323. doi:10.1021/ol8007952

90. Hulot, C.; Blond, G.; Suffert, J. J. Am. Chem. Soc. 2008, 130, 5046. doi:10.1021/ja800691c

91. Benson, C. L.; West, F. G. Org. Lett. 2007, 9, 2545. doi:10.1021/ol070924s

92. Pouwer, R. H.; Schill, H.; Williams, C. M.; Bernhardt, P. V. Eur. J. Org. Chem. 2007, 4699. doi:10.1002/ejoc.200700367

93. Jung, M. E.; Min, S.-J. Tetrahedron 2007, 63, 3682. doi:10.1016/j.tet.2007.02.085

94. Sünnemann, H. W.; Banwell, M. G.; de Meijere, A. Eur. J. Org. Chem. 2007, 3879. doi:10.1002/ejoc.200700201

95. Tessier, P. E.; Nguyen, N.; Clay, M. D.; Fallis, A. G. Org. Lett. 2005, 7, 767. doi:10.1021/ol047602y

96. Greshock, T. J.; Funk, R. L. J. Am. Chem. Soc. 2006, 128, 4946. doi:10.1021/ja060282o

97. Yu, T.-Q.; Fu, Y.; Liu, L.; Guo, Q.-X. J. Org. Chem. 2006, 71, 6157. doi:10.1021/jo060885i

98. Magomedov, N. A.; Ruggiero, P. L.; Tang, Y. J. Am. Chem. Soc. 2004, 126, 1624. doi:10.1021/ja0399066

99. Barluenga, J.; Merino, I.; Palacios, F. Tetrahedron Lett. 1990, 31 , 6713. doi:10.1016/S0040-4039(00)97155-7

100. Martínez, R.; Jiménez-Vázquez, H. A.; Delgado, F.; Tamariz, J. Tetrahedron 2003, 59, 481. doi:10.1016/S0040-4020(02)01536-3

101. Wallace, D. J.; Klauber, D. J.; Chen, C. Y.; Volante, R. P. Org. Lett. 2003, 5, 4749. doi:10.1021/ol035959g

102.Wabnitz, T. C.; Yu, J.-Q.; Spencer, J. B. Chem.-Eur. J. 2004, 10, 484 doi:10.1002/chem.200305407

103.Spangler, C. W.; Jondahl, T. P.; Spangler, B. J. Org. Chem. 1973, 38, 2478. doi:10.1021/jo00954a013

104.Guner, V. A.; Houk, K. N.; Davies, I. A. J. Org. Chem. 2004, 69, 8024 doi:10.1021/jo048540s

105.Duncan, J. A.; Calkins, D. E. G.; Chavarha, M. J. Am. Chem. Soc. 2008, 130, 6740. doi:10.1021/ja074402j 


\section{License and Terms}

This is an Open Access article under the terms of the Creative Commons Attribution License

(http://creativecommons.org/licenses/by/2.0), which permits unrestricted use, distribution, and reproduction in any medium, provided the original work is properly cited.

The license is subject to the Beilstein Journal of Organic Chemistry terms and conditions:

(http://www.beilstein-journals.org/bjoc)

The definitive version of this article is the electronic one which can be found at:

doi:10.3762/bjoc. 7.53 